\title{
Margaret McCartney: Doctors should care about cycling
}

\author{
Margaret McCartney general practitioner
}

Glasgow

Charlie Alliston was recently convicted of "wanton and furious driving” and jailed for 18 months. A pedestrian, Kim Briggs, was killed when Alliston, riding a bicycle that was not fitted with a front brake, collided with her in London in 2016. ${ }^{1}$

In the wake of his conviction we've heard significant murmurings from the media that cyclists, as part of a "minority activity," have had it too easy. Some suggest that cyclists not only require some form of regulation but are responsible for causing car congestion, as bike lanes are allegedly underused. ${ }^{2}$ A police and crime commissioner in England has called for cyclists to have some kind of registration display. ${ }^{3}$

The government, in the meantime, has responded by accelerating a review of the law (pending since 2014) to "consider whether a new offence equivalent to causing death by careless or dangerous driving should be introduced for cyclists." This review will have two phases. The first will consider whether a new cycling offence should be placed into statute. The second is a consultation about road safety and "the different ways in which safety can be further improved between cyclists, pedestrians, and motorists."

Active commuting, including cycling, is associated with reductions in mortality, cardiovascular disease, and cancer

Doctors should care about cycling, as it's one of the best preventive health interventions we have. Active commuting, including cycling, is associated with reductions in mortality, cardiovascular disease, and cancer. ${ }^{56}$ Body mass index and the percentage of body fat are lower in active commuters. ${ }^{7} \mathrm{Car}$ drivers who switch to commuting by bike report slightly higher wellbeing scores. ${ }^{8}$

And it's not just the individual cyclist who benefits. In every area of London, air pollution now exceeds World Health Organization air quality guidelines. ${ }^{9}$ Car drivers who switch to a bike will reduce air pollution, and, since we know that pollution has significant adverse health effects, ${ }^{10}$ this will benefit society in general.

The government says that, "in 2015, two pedestrians were killed and 96 seriously injured after being hit by a bicycle. Every year more than 100 cyclists are killed and more than 3000 seriously injured on British roads." This is true, and it's not the whole story. The annual average number of pedestrians killed by a car from 2011 to 2015 was 215 , and 3913 were seriously injured. The scale of injury caused to pedestrians by bikes is dwarfed by the damage caused by cars. ${ }^{11}$

I'm concerned that the tragic Alliston case will be used to create laws and restrictions that won't make pedestrians and citizens safer or healthier. It may result in changes that make cycling a harder option, not an easier one. In Copenhagen some $45 \%$ of journeys to work and education are made by bike, and cyclists find this faster and easier. ${ }^{12}$ It's also good for their health and for others living in Copenhagen.

Contrary to perception, Denmark lost its reputation as a cycling city in the mid-1960s, amid a realisation that it had become polluted and dangerous to cycle in. It required commitment, infrastructure, public buy-in, and encouragement to create the magnificent cycleways it now has. ${ }^{13}$ We need the same vision in the UK-and, to do that, we need plain sight of where the dangers are.

Competing interests: I love my bike. I also own a car. See www.bmj. com/about-bmj/freelance-contributors/margaret-mccartney.

Provenance and peer review: Commissioned; not externally peer reviewed.

Follow Margaret on Twitter, @mgtmccartney

1 Gayle D. Cyclist Charlie Alliston jailed for 18 months over death of pedestrian. Guardian 18 Sept 2017. https://www.theguardian.com/lifeandstyle/2017/sep/18/cyclist-charliealliston-jailed-for-18-months-over-death-of-pedestrian.

2 Boulton A. At last the wheels are coming off our senseless worship of bicycles[login required]. Sunday Times 27 Aug 2017. https://www.thetimes.co.uk/article/at-last-thewheels-are-coming-off-our-senseless-worship-of-bicycles-stvzcxb7s.

3 Walker P. Police commissioner proposes ID for cyclists-but can't explain why or how. Guardian 9 Oct 2014. https://amp.theguardian.com/environment/bike-blog/2014/oct/09/ police-commissioner-proposes-id-for-cyclists-but-cant-explain-why-or-how.

4 Department for Transport. Norman J. Government launches urgent enquiry into cycle safety. 21 Sept 2017. https://www.gov.uk/government/news/government-launches-urgentreview-into-cycle-safety.

5 Celis-Morales CA, Lyall DM, Welsh P, et al. Association between active commuting and incident cardiovascular disease, cancer, and mortality: prospective cohort study. BMJ 2017;359:j1456. doi:10.1136/bmj.j1456 pmid:28424154

6 Oja P, Titze S, Bauman A, et al. Health benefits of cycling: a systematic review. Scand Med Sci Sports 2011;359:496-509. doi:10.1111/1.1600-0838.2011.01299.x. pmid:21496106.

7 Flint E, Cummins S, Sacker A. Associations between active commuting, body fat, and body mass index: population based, cross sectional study in the United Kingdom. BMJ 2014;359:g4887. doi:10.1136/bmj.g4887 pmid:25139861. 
8 Martin A, Goryakin Y, Suhrcke M. Does active commuting improve psychological wellbeing? Longitudinal evidence from eighteen waves of the British Household Panel Survey. Prev Med 2014;359:296-303. https://doi.org/10.1016/j.ypmed.2014.08.023. doi:10.1016/j.ypmed. 2014.08.023 pmid:25152507.

9 London Datastore. PM2.5 map and exposure data. 4 Oct 2017. https://data.london.gov. uk/dataset/pm2-5-map-and-exposure-data.

10 Hawkes N. Air pollution in UK: the public health problem that won't go away. BMJ 2015;359:h2757. doi:10.1136/bmj.h2757 pmid:26001592.

11 Cycling UK. Campaigns briefing 4R: Cycling and pedestrians. Oct 2016. https://www. cyclinguk.org/sites/default/files/document/2017/10/pedestrians_4r_brf.pdf.
12 Technical and Environmental Association. Copenhagen - city of cyclists: the bicycle account 2014. May 2015. www.cycling-embassy.dk/wp-content/uploads/2015/05/ Copenhagens-Biycle-Account-2014.pdf.

13 Carstensen TA, Olaffsson AS, Bech NM, Poulsen TS, Zhao C. The spatio-temporal development of Copenhagen's bicycle infrastructure 1912-2013. Geogr Tidsskr-Dan. J Geog 2015;359:142-56. doi:10.1080/00167223.2015.1034151.

Published by the BMJ Publishing Group Limited. For permission to use (where not already granted under a licence) please go to http:/group.bmj.com/group/rights-licensing/ permissions 